\title{
Measurement of serum lactate values in domestic cats (Felis catus) submitted to physical and chemical restraint
}

\author{
Mensuração dos valores de lactato sérico em felinos domésticos (Felis catus) \\ submetidos a contenção física e química
}

Rafael Henrique de Souza SIRAGUSI'; ${ }^{1}$ Valeska Tallia Mendes de BARROS ${ }^{1}$; Emiliana Andrade FIORINI'; Tiago Montalvão BERGAMO ${ }^{1}$; Rafael Cerântola SIQUEIRA²; Fábio Fernando Ribeiro MANHOSO²; Rodrigo Prevedello FRANCO $^{2}$

${ }^{1}$ Universidade de Marília, Hospital Veterinário, Clínica Médica e Cirúrgica de Pequenos Animais, Marília - SP, Brazil

${ }^{2}$ Universidade de Marília, Faculdade de Ciências Agrárias, Curso de Medicina Veterinária, Marília - SP, Brazil

\begin{abstract}
The use of serum lactate has become increasingly common in Veterinary Medicine, since it is an excellent marker of tissue oxygenation, elevated in situations of tissue hypoxia, where anaerobic glycolysis is used as an energy source. Studies point out its use in dogs as a prognostic factor in several affections; however it is not commonly used in domestic felines due to the high stress threshold of the species, which may interfere with their values. The aim of the present study was to evaluate serum lactate values in domestic cats during physical restraint and after chemical restraint using the combination of $8 \mathrm{mg} / \mathrm{kg}$ ketamine-S, $0.4 \mathrm{mg} / \mathrm{kg}$ midazolam, and $2 \mathrm{mg} / \mathrm{kg}$ Tramadol. To this end, 20 clinically healthy female cats without defined race, from six months to five years of age, were divided into two groups, GPR (n $=10)$ represented by felines that had only physical restraint and the GCR $(n=10)$ by felines that underwent physical restraint (TPR) and after 30 hours by chemical restraint (TCR). It was observed that in both groups (GPR and CPR) during physical restraint presented hyperlactatemia (GPR $=6.23 \pm 0.9 \mathrm{mmol} / \mathrm{L}-\mathrm{GCR}-\mathrm{Tpr}=6.66 \pm 1.59 \mathrm{mmol} / \mathrm{L}$ ) and mean values of $4.42 \pm 1.28 \mathrm{mmol} / \mathrm{L}$ during chemical restraint (GCR - Tcr). It was concluded that physical restraint interferes with serum lactate values, with the reduction of such values with the use of chemical restraint in the feline species.
\end{abstract}

Keywords: Lactate. Felines. Physical containment. Chemical containment.

\section{Resumo}

A utilização do lactato sérico é cada vez mais comum na Medicina Veterinária, por ser um excelente marcador de oxigenação tecidual, elevando-se em situações de hipóxia tecidual e realizando a glicólise anaeróbica como fonte de energia. Pesquisas científicas em cães o apontam como fator prognóstico em diversas afecções, sendo pouco utilizado em felinos domésticos devido ao elevado limiar de estresse da espécie, podendo interferir em seus valores. Assim, este trabalho avaliou os valores de lactato sérico em felinos domésticos durante contenção física e após contenção química, utilizando a associação de $8 \mathrm{mg} / \mathrm{kg}$ de cetamina-S, 0,4 mg/kg de midazolam e $2 \mathrm{mg} / \mathrm{kg}$ de cloridrato de tramadol. Foram estudados 20 felinos, fêmeas, sem raça definida, de seis meses a cinco anos de idade, clinicamente saudáveis, divididos em dois grupos, com GPR $(n=10)$ representado por felinos que passaram apenas por contenção física e com GCR por felinos que passaram por contenção física (TPR) e após 30 horas por contenção química (TCR). Foi observado em ambos os grupos (GPR e GCR) e durante a contenção física a hiperlactatemia sérica (GPR $=6.23 \pm 0.9 \mathrm{mmol} / \mathrm{L}-$ GCR - TPR $=6.66 \pm 1.59 \mathrm{mmol} / \mathrm{L}$ ) com valores médios de 4,42 $\pm 1,28 \mathrm{mmol} / \mathrm{L}$ durante a contenção química (GCR - TCR). Conclui-se que a contenção física interfere nos valores do lactato sérico, com redução dos valores na utilização da contenção química na espécie felina.

Palavras-chave: Lactato. Felinos. Contenção física. Contenção química. 
Correspondence to:

Rafael Henrique de Souza Siragusi

Universidade de Marília, Faculdade de Ciências Agrárias,

Curso de Medicina Veterinária

Avenida Higyno Muzzy Filho, 1001

CEP 17525-902, Marília, SP, Brazil

e-mail: rafaelsiragusi@hotmail.com

Received: 09/05/2017

Approved: 17/11/2017

\section{Introduction}

The importance of the evaluation of serum lactate was first described in 1780 in Human Medicine. Currently its use in the routine of Veterinary Medicine is increasing due to its importance as marker of tissue oxygenation and prognostic factor in several affections (ACIERNO et al., 2008). Lactate is an organic compound found in muscles, blood, and other organs, originated from the metabolism of carbohydrates and mainly glucose, produced in situations of anaerobiosis to be used as a source of organic energy, in situations of tissue hypoxia (SILVA et al., 2001). Hyperlactatemia occurs when lactate production exceeds its metabolism and elimination, in situations such as tissue hypoxia resulting from systemic oxygen reduction (PANG; BOYSEN, 2007; ALLEN; HOLM, 2008). In adult dogs normal serum lactate values can range from $0.3-2.5 \mathrm{mmoL} / \mathrm{L}$, with studies indicating its use as a prognostic factor and marker of tissue hypoxia in sepsis, peritonitis, dilatation, and torsion gastric volvulus, immune-mediated hemolytic anemia, cerebral ischemia, healing tissues, and especially in general emergency situations (CAINES et al., 2013; CORTELLINI et al., 2014; MOONEY et al., 2014). In domestic cats normal values of serum lactate are 0.5-2.5 mmol/L (SHARKEY; WELLMAN, 2013) measured by minimally invasive techniques using venous blood (VERNON; LETOURNEAU, 2010; SHARKEY; WELLMAN, 2013), and the normal heart rate is between $120-240 \mathrm{bpm}$, respiratory rate $20-40$ $\mathrm{mpm}$, and temperature 37.8 to $39.2^{\circ} \mathrm{C}$ (FEITOSA, 2014).

Stress in the feline species is related to changes in the environment, such as interaction with humans and animals of another species and unknown animals (AMAT et al., 2015).

Due to the high stress threshold of the feline species, demonstrated by vocalization, struggle, and attempted escape form restraint, there may be influences on the

measured values, resulting in hyperlactatemia even in healthy felines (RAND et al., 2002). The stress factor results in alterations in homeostasis, leading to the activation of the hypothalamic pituitary-adrenal axis and activation of the sympathetic nervous system, which stimulates the nerve and adrenal medullary terminals to release epinephrine, norepinephrine, and dopamine, which occurs mainly in acute stress (SHARKEY, WELLMAN, 2015). These hormonal activities may result in vasoconstriction and decreased tissue perfusion (RAND et al., 2002), being more noticeable in felines (ACIERNO et al., 2008).

Quimby et al. (2011), in their research at the University of Colorado - USA, tried to demonstrate that these stressors present in the management of felines cause changes in the vital clinical parameters of the animals. To that end the physiological parameters of healthy domestic cats submitted to a visit to the university's Veterinary Hospital were assessed both when they were obtained in their homes and at the hospital, showing a considerable increase in heart and respiratory rate, blood pressure, and temperature when the animals were taken to the Veterinary Hospital evidences of stress in the felines studied.

Acierno et al. (2008) reported a variation in serum lactate values between 0.4 and $13.7 \mathrm{mmol} / \mathrm{L}$ in a study conducted at the University of Louisiana - USA, with 47 domestic cats, concluding that the variables mentioned above can be observed. That variation in values makes standardization difficult in feline patients, corroborating with Rand et al. (2002), in which they obtained similar results by subjecting 20 clinically healthy feline patients to five-minute baths in a shower tube, and then were dried with towels for two minutes, observing a peak of hyperlactatemia in all cats during the bath stabilizing only two hours later. Thus, they suggested that the stress caused by the bath was responsible for hyperlactatemia in felines.

On the other hand, considering the stress caused by physical restraint at the moment of collection, Redavid et al. (2012) conducted a survey at the West Bridewater / Massachusetts Veterinary Medical Center where they assessed serum lactate values in 21 healthy domestic felines at three distinct times: at the time of arrival of the animals, after one hour, and after 24 hours. The results did not show significant differences $(p=0.13)$ between the values measured during the studied times, 
suggesting that serum lactate can be measured with confidence in domestic felines, as it is done in dogs.

\section{Objective}

The aim of this study was to evaluate serum lactate values in domestic felines (Felis catus) submitted to physical and chemical restraint.

\section{Materials and Methods}

For the accomplishment of the present study, approved by the Committee of Ethics of animal use, under the protocol \#037/2015, 26 female domestic felines (Felis catus) were used, all without defined race, of age ranging from six months to five years, which after clinical and laboratory evaluation (hemogram, urea, creatinine, gamma-glutamyltransferase, and alkaline phosphatase) should be clinically healthy. Six cats presented laboratory alterations, being excluded from the present study and sent to the sector responsible for treatment, totalizing the amount of 20 felines studied.

The felines were brought to the Veterinary Hospital of the University of Marília - UNIMAR for consultation, undergoing screening, clinical, and laboratory evaluation. They were divided into two groups: Group of Physical Restraint (GPR), composed of 10 domestic cats, was were submitted to physical restraint in order to perform the clinical and physical examination, assessing heart rate (HR), respiratory rate), rectal temperature (T), and peripheral pulse. Subsequently, $3 \mathrm{~mL}$ of venous blood were collected from the jugular vein to perform the laboratory tests. Then, $0.1 \mathrm{~mL}$ of blood from the cephalic vein was collected to measure serum lactate using Accutrend Plus ${ }^{\circledast}$ portable lactimetry meter and later released home.

Group of Chemical Restraint (GCR), composed of 10 felines that were brought to the Unimar HV for elective castration, underwent screening, clinical and laboratory evaluation, and physical restraint - Time of Physical restraint (TPR) -, all procedures performed equally to the GPR group. However, all cats of GCR group were referred to the inpatient department for a period of 30 hours, where food and water ad libitum, bed and area box were offered for 24 hours, in addition to the recommendation of a quiet, sanitized and ventilated area; and for six hours, prior to the surgical procedure, water and food fasting were performed. The cats were referred to the Surgery Sector and were physically restrained to be anesthetized with dissociative anesthesia, consisting of $8 \mathrm{mg} / \mathrm{kg}$ Ketamine-S, $0.4 \mathrm{mg} / \mathrm{kg}$ Midazolam, and $2 \mathrm{mg} /$ $\mathrm{kg}$ Tramadol Hydrochloride, all intramuscularly. After 15 minutes, there was postural loss, indicating sedation of the patients - Time of Chemical Restraint (TCR) -, at which time the $\mathrm{HR}, \mathrm{RR}$, and rectal temperature were collected and $0.1 \mathrm{~mL}$ of cephalic vein blood was collected for lactate measurement in the animals under dissociative anesthesia. They were then submitted to elective ovarian-hysterectomy.

Serum lactate values were submitted to statistical analysis, Shapiro-Wilk, Kolmogorov-Smirnov, Cramervon Mises, and Anderson-Darling to check the normality of sample and the T-Student distribution, and the GPR serum lactate was compared in the physical containment with the lactate of the chemical containment of group GCR (TCR), and Paired t-test for comparison of serum lactate of group GCR in the two times, physical restraint (TPR) and chemical restraint (TCR). Values of clinical parameters, heart rate, respiratory rate, and temperature were correlated through the Pearson Correlation Coefficient in order to verify the correlation between them with serum lactate in physical restraint (GPR and GCR groups) and with serum lactate in the chemical restraint (TCR).

\section{Results and Discussion}

Data from 20 clinically healthy cats lacking laboratory abnormalities, divided into GPR group $(\mathrm{n}=10)$ and GCR group $(n=10)$, and the parameters measured were obtained and evaluated.

Comparing the serum lactate values in physically contained GPR group and cats of GCR group (time TCR), a significant difference was observed between groups, with GPR values higher than GCR (Table 1), results similar to those observed by Acierno et al. (2008) and Rand et al. (2002), who observed high hyperlactatemia in felines submitted to physical stress, which may be justified due to the activation of the sympathetic nervous system and the hypothalamic-adrenal axis, caused by the stress caused by the physical restraint, resulting in hyperlactatemia (ACIERNO et al., 2008). However, due to chemical containment there is muscle relaxation, decreased sensory stimuli and analgesia (AKKERDAAS et al., 2001; BRONDANI et al., 2003), resulting in lower values. 
Table 1 - Comparison of mean values and standard deviations of serum lactate in healthy cats, submitted to physical restraint (GPR) and chemical (GCR - TCR)

\begin{tabular}{lccccc}
\hline VARIANT & $\begin{array}{c}\text { Mean } \\
\text { (mmol/L) }\end{array}$ & $\begin{array}{c}\text { S.D. (Standard } \\
\text { deviations) }\end{array}$ & Minimum (mmol/L) & $\begin{array}{c}\text { Maximum } \\
\text { (mmol/L) }\end{array}$ & p-value \\
\hline GPR & 6,23 & $\pm 0,93$ & 4,9 & 7,8 & 0,002 \\
CR-TCR & 4,42 & $\pm 1,28$ & 2 & 6,6 & \\
\hline
\end{tabular}

In order to compare the serum lactate values using the same felines, both physically and chemically restrained, the GCR group was divided into two times: physical restraint (TPR) and chemical restraint (TCR), with values showing significant differences and higher values during the physical restraint (TPR) (Table 2), demonstrating hyperlactatemia during physical restraint superior to the hyperlactatemia of the chemical restraint, even when carried out in the same animals, emphasizing that the stress caused by physical restraint elevates the lactate in the felines (RAND et al., 2002; ACIERNO et al., 2008). The animals in the present study stayed for 30 hours in a hospital environment, where they were handled by veterinarians for sample collection and food-sanitary management, factors that may be stressful stimuli for the feline species as described by Amat et al. (2015).

Table 2 - Comparison of mean values and standard deviations of serum lactate obtained in chemical restraint (CR) cats, subjected to physical and chemical restraint (TPR and TCR)

\begin{tabular}{lccccc}
\hline VARIANT & $\begin{array}{c}\text { Mean } \\
\text { (mmol/L) }\end{array}$ & $\begin{array}{c}\text { S.D. (Standard } \\
\text { deviations) }\end{array}$ & Minimum (mmol/L) & $\begin{array}{c}\text { Maximum } \\
\text { (mmol/L) }\end{array}$ & p-value \\
\hline CR - TPR & 6,66 & $\pm 1,59$ & 4,2 & 9,8 & 0,0167 \\
CR - TCR & 4,42 & $\pm 1,28$ & 2 & 6,6 & \\
\hline
\end{tabular}

Regarding the clinical variables, heart rate, respiratory rate and temperature, measured during the clinical examination of the patients, previous to the physical containment for blood collection, and after chemical containment was not obtained correlation mean $(\mathrm{p}<0.05)$ with the serum lactate values in both groups. The measured physiological parameters such as heart rate (HR bpm), respiratory rate (RR $\mathrm{mpm})$, and temperature $\left(\mathrm{T}^{\circ} \mathrm{C}\right)$ remained within the normal range for the species (FEITOSA, 2014) in both groups studied and showing no differences between them. On the one hand, the GPR group presented mean values of HR $181.1 \pm 19.5$, RR $45.5 \pm 9.0$, and $\mathrm{T} 038.7 \pm 0.3$. On the other hand, the animals that received physical restraint after 24 hours of hospital environment (GCR group) had HR values $184.0 \pm 23.7, \mathrm{RR} 44.9 \pm 10.4$, and $\mathrm{T}$ 038.9 $\pm 0.3(\mathrm{P}>0.055)$, thus the values of $\mathrm{RR} 34.3 \pm 4.8(\mathrm{p}>0.058)$ and $\mathrm{T}^{\circ}$ were reduced $(\mathrm{p}>0.05)$ after chemical containment, with $H R$ values of $154.2 \pm 12.3$ and $T 038.1 \pm 0.1$. It is suggested that the acute stress caused by physical restraint, through the activation of the sympathetic nervous system, may not be the primary and immediate cause for the increase in serum lactate, but a chronic neuroendocrine and sympathetic activation that the animal may present from the moment of restraint at home and transportation to the Veterinary Hospital, considering that felines may be less tolerant to manipulations in their own territories (QUIMBY et al., 2011). During the chemical restraint, the use of ketamine-S, Midazolan, and Tramadol Hydrochloride influenced the reduction of serum lactate values, depressant action in the respiratory system and in the thermoregulatory center, activation of sympathetic tone, muscular myorelaxation, and hypnosis (BRONDANI et al., 2003).

\section{Conclusion}

In the evaluation of the obtained results it can be concluded that the values in the physical restraint are larger when compared to the felines under containment anesthesia. It should be emphasized that environmental factors and the manipulation of the species influence the increase of basal values, and may compromise the use of serum lactate in the prognosis of diseased felines.

\section{References}

ACIERNO, M. J.; JOHNSOM, M. E.; EDDLEMAN, L. A.; MITCHELL, M. A. Measuring statistical agreement between four point of care (POC) lactate meters and a laboratory analyzer in cats. Journal of Feline Medicine 
and Surgery, v. 10, n. 2, p. 110-114, 2008. doi: 10.1016/j. jfms.2007.07.002.

AKKERDAAS, L. C.; MIOCH, P.; SAP, R.; HELLEBREKERS, L. J. Anaesthesiology: cardiopulmonary effects of three different anaesthesia protocols in cats. The Veterinary Quarterly, v. 23, n. 4, p. 182-186, 2001. doi: 10.1080/01652176.2001.9695109.

ALLEN, S. E.; HOLM, J. L. Lactate: physiology and clinical utility. Journal of Veterinary Emergency and Critical Care, v. 18, n. 2, p. 123-132, 2008. doi: 10.1111/j.14764431.2008.00286.x.

AMAT, M.; CAMPS, T.; MANTECA, X. Stress in owned cats: behavioural changes and welfare implications. Journal of Feline Medicine and Surgery, v. 18, n. 8, p. 577-586, 2015. doi: 10.1177/1098612X15590867.

BRONDANI, J. T.; NATALINI, C. C.; PIPPI, N. L.; MAZZANTI, A.; PRATI, L.; BERTIN, A. P. Anestesia com cetamina, midazolam e óxido nitroso em cães submetidos à esofagoplastia cervical. Ciência Rural, v. 33, n. 6, p. 10751080, 2003. doi: 10.1590/S0103-84782003000600012.

CAINES, D.; SINCLAIR, M.; WOOD, D.; VALVERDE, A.; DYSON, D.; GAITERO, L.; NYKAMP, S. Evaluation of cerebrospinal fluid lactate and plasma lactate concentrations in anesthetized dogs with and without intracranial disease. Canadian Journal of Veterinary Research, v. 77, n. 4, p. 297-302, 2013.

CORTELLINI, S.; SETH, M.; KELLETT-GREGORY, L. M. Plasma lactate concentrations in septic peritonitis: a retrospective study of 83 dogs (2007-2012). Journal of Veterinary Emergency and Critical Care, v. 25, n. 3, p. 388-395, 2014. doi: 10.1111/vec.12234.

FEITOSA, F. L. F. Semiologia veterinária: a arte do diagnóstico. 3. ed. São Paulo: Roca, 2014.

MOONEY, E.; RAW, C.; HUGHES, D. Plasma lactate concentration as prognostic biomarker in dogs with gastric dilation and volvulus. Topics in Companion Animal Medicine, v. 29, n. 3, p. 71-76, 2014. doi: 10.1053/j. tcam.2014.09.005.

PANG, D. S.; BOYSEN, S. Lactate in veterinary critical care: pathophysiology and management. Journal of the American Animal Hospital Association, v. 43, n. 5, p. 270-279, 2007. doi: 10.5326/0430270.

QUIMBY, J. M.; SMITH, M. L.; LUNN, K. F. Evaluation of the effects of hospital visit stress on physiologic parameters in the cat. Journal of Feline Medicine and Surgery, v. 13, n. 10, p. 733-737, 2011. doi: 10.1016/j.jfms.2011.07.003.

RAND, J. S.; KINNAIRD, E.; BAGLIONI, A.; BLACKSHAW, J.; PRIEST, J. Acute stress hyperglycemia in cats is associated with struggling and increased concentrations of lactate and norepinephrine. Journal of Veterinary Internal Medicine, v. 16, n. 2, p. 123-132, 2002. doi: 10.1111/j.1939-1676.2002.tb02343.x.

REDAVID, L. A.; SHARP, C. R.; MITCHELL, M. A.; BECKEL, N. F. Plasma lactate measurements in healthy cats. Journal of Veterinary Emergency and Critical Care, v. 22, n. 5, p. 580-587, 2012. doi: 10.1111/j.14764431.2012.00801.x.

SHARKEY, L. C.; WELLMAN, M. L. Use of lactate in small animal clinical practice. Veterinary Clinics of North America: Small Animal Practice, v. 43, n. 6, p. 1287-1297, 2013. doi: 10.1016/j.cvsm.2013.07.012.

SILVA, E.; GARRIDO, A. G.; ASSUNÇÃO, M. S. C. Avaliação da perfusão tecidual no choque. Medicina: Ribeirão Preto, v. 34, n. 1, p. 27-35, 2001. doi: 10.11606/ issn.2176-7262.v34ilp27-35.

VERNON, C.; LETOURNEAU, J. L. Lactic acidosis: recognition, kinetics, and associated prognosis. Critical Care Clinics, v. 26, n. 2, p. 255-283, 2010. doi: 10.1016/j. ccc.2009.12.007. 